\title{
Synthesis of the calcilytic ligand NPS 2143
}

\author{
Henrik Johansson ${ }^{1}$, Thomas Cailly ${ }^{1,2}$, Alex Rojas Bie Thomsen ${ }^{1}$, \\ Hans Bräuner-Osborne ${ }^{1}$ and Daniel Sejer Pedersen ${ }^{* 1}$
}

\section{Full Research Paper}

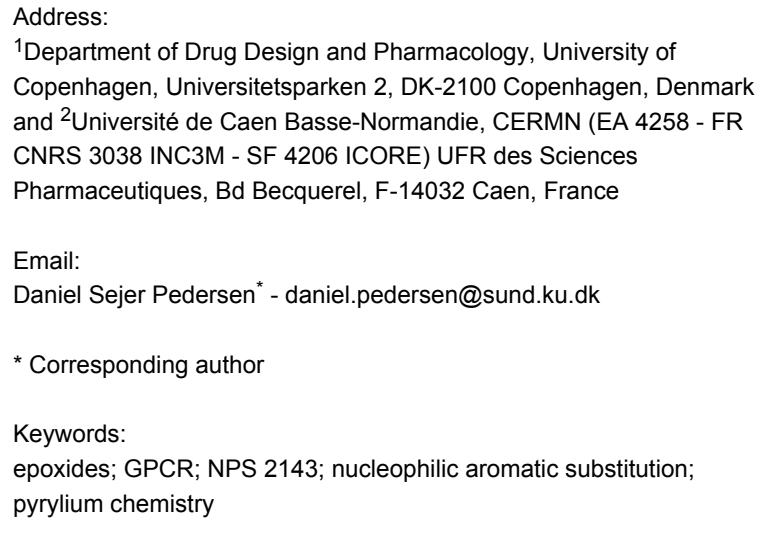

\begin{abstract}
$(R)-3$ (NPS 2143) is a negative allosteric modulator of the human calcium-sensing receptor (CaSR) and as such represents an important pharmacological tool compound for studying the CaSR. Herein, we disclose for the first time a complete experimental description, detailed characterisation and assessment of enantiomeric purity for $(R)$-3. An efficient, reproducible and scalable synthesis of $(R)-3$ that requires a minimum of chromatographic purification steps is presented. $(R)-\mathbf{3}$ was obtained in excellent optical purity (er > 99:1) as demonstrated by chiral HPLC and the pharmacological profile for $(R)-\mathbf{3}$ is in full accordance with that reported in the literature.
\end{abstract}

\section{Introduction}

The first G-protein-coupled receptors (GPCRs) were identified more than 30 years ago and have since grown to become the largest class of membrane-bound receptors and the single most common target type in drug discovery and therapy $[1,2]$. Excluding olfactory receptors there are 390 genes encoding GPCRs in the human genome, divided into three major classes (A, B and C) of which the rhodopsin-like class A is the largest and most diverse, and which has been well-studied and subject to drug targeting [3]. GPCR class $\mathrm{C}$ is much smaller and comprises only 22 known receptors including eight metabotropic glutamate (mGlu) receptors, two $\gamma$-aminobutyric

acid type $B\left(G_{A B A}\right)$ receptors, three taste $(T R)$ receptors, the GPRC6A receptor, the calcium-sensing receptor (CaSR), and seven orphan receptors [4]. Class C GPCRs have proven viable as drug targets, exemplified by the marketed $\mathrm{GABA}_{\mathrm{B}}$ agonist baclofen, and by cinacalcet (1), a positive allosteric modulator on the CaSR (1, Figure 1) [5].

The CaSR is the main regulator of serum calcium homeostasis and plays a central role in several cellular processes such as secretion and regulation of peptide hormones (most importantly parathyroid hormone), ion-channel activity and apoptosis in 
1<smiles>C[C@H](NCCCc1cccc(C(F)(F)F)c1)c1cccc2ccccc12</smiles>

2<smiles>CC(NC1CCCCC1NC(=O)c1ccc(Cl)cc1)c1cccc2ccccc12</smiles>

3<smiles>CC(C)(Cc1ccc2ccccc2c1)NC[C@@H](O)COc1cccc(Cl)c1C#N</smiles>

Figure 1: Marketed calcium-sensing receptor agonist cinacalcet (1), and CaSR antagonists Calhex 231 (2) and NPS $2143((R)-3)$.

certain cell types [6-8]. The CaSR is involved in several calcium-regulation-related diseases including various types of hypo- and hyperparathyroidism, and its pronounced regulation of parathyroid hormone secretion makes it an interesting target for drug discovery [9]. Several potent CaSR modulators have been reported over the past decade, including the negative allosteric modulators (calcilytics) 2 [10] and ( $R$ )-3 (Figure 1) $[11,12]$.

To facilitate our pharmacological research program on the CaSR we required calcilytic $(R)-\mathbf{3}$ in quantities of several grams as a pharmacological tool compound. We quickly discovered that the published [12-14] experimental details and characterisation for ligand $(R)-\mathbf{3}$ were unsatisfactory, and we were unable to reproduce several of the reported synthetic procedures. Moreover, we were surprised to discover the lack of assessment of optical purity for $(R)-3$. Considering that the $R$-enantiomer of $(R)$-3 and related aminoalcohols display both significantly higher potency and target selectivity than their $S$-enantiomers, we believe that this is a critical shortcoming in the previously reported syntheses $[13,14]$.

Herein, we wish to report a detailed, reproducible and scalable synthesis for racemic and enantiopure calcilytic agent $(R)-\mathbf{3}$, including detailed spectroscopic, chromatographic and pharmacological characterisation.

\section{Results and Discussion}

We decided to synthesise $(R)-\mathbf{3}$ using the same overall strategy published by others employing the three fragments depicted in Scheme 1. Similar to a previously reported synthesis of $(R)-\mathbf{3}$ [13], we decided to activate epoxide $\mathbf{5}$ as the $m$-nosyl derivative that has been shown to minimise racemisation during epoxide ring opening [15].

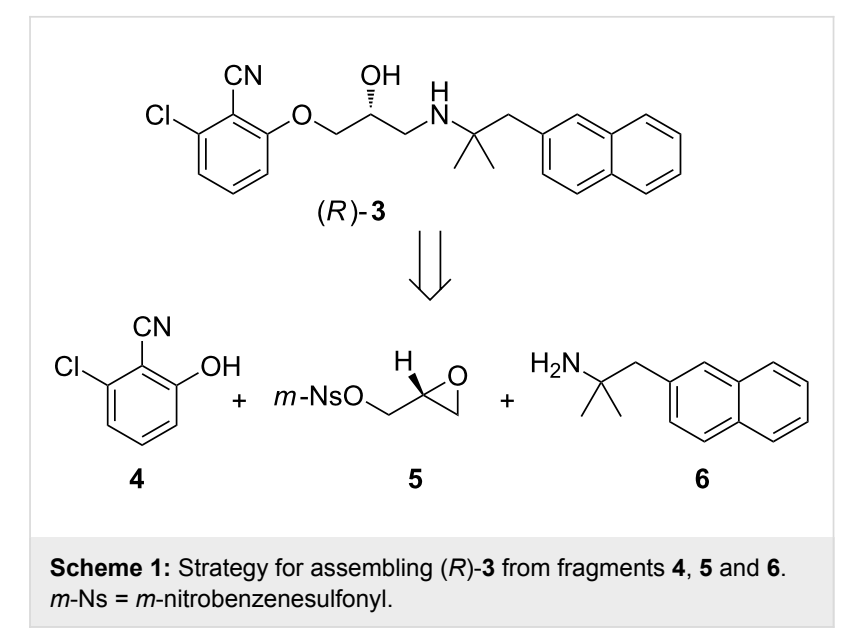

The synthesis of amine $\mathbf{6}$ was accomplished from commercially available 2-cyanonaphthalene (7) in four steps (Scheme 2). Reduction of 7 was easily achieved on multigram scale by using $\mathrm{LiAlH}_{4}$ to provide amine $\mathbf{8}$ in excellent yield and purity after work-up. According to the method of Katritzky et al. [16] amine $\mathbf{8}$ was activated as the corresponding pyridinium salt $\mathbf{1 0}$ upon treatment with triphenylpyrylium salt $\mathbf{9}$ in ethanol under reflux. Subsequently, the crude pyridinium salt $\mathbf{1 0}$ was exposed to the sodium salt of 2-nitropropane (11) to give nitro compound $\mathbf{1 2}$. Reduction of the nitro group in $\mathbf{1 2}$ by catalytic hydrogenation at atmospheric pressure to produce amine $\mathbf{6}$ has previously been described by Kamal and Chouhan [17] but was unsuccessful in our hands, returning the starting material under a variety of conditions. Eventually, the reduction was realised using zinc and $\mathrm{HCl}$ in ethanol to give amine 6 in good yield after chromatographic purification.

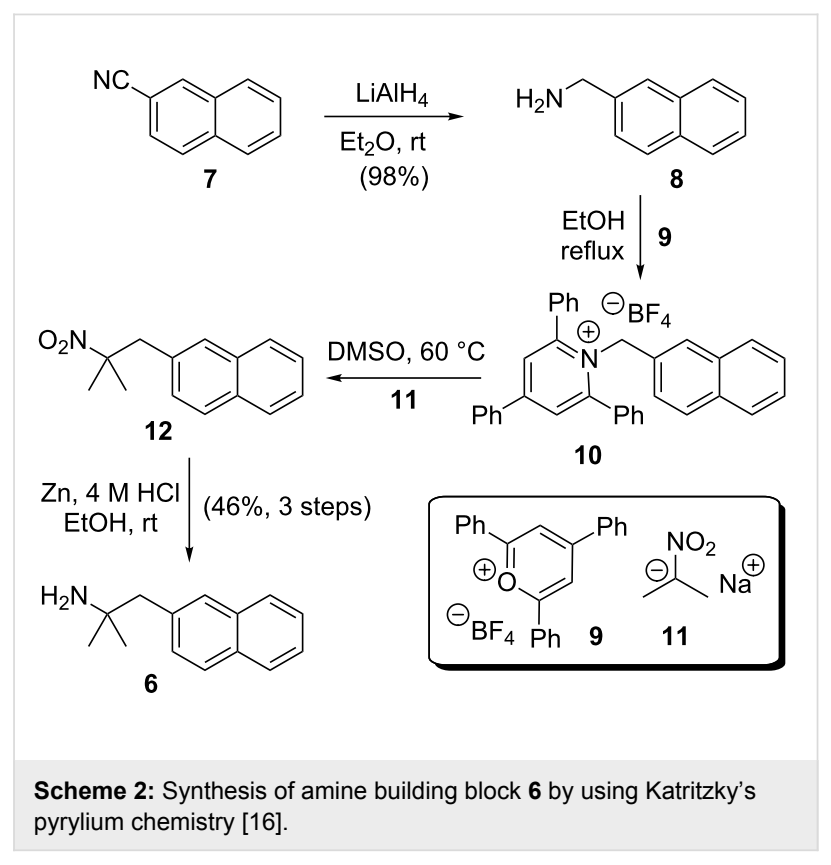


Next we turned our attention to the synthesis of phenol 4 (Scheme 3). Previously, 4 has been synthesised by nucleophilic aromatic substitution on commercially available aryl fluoride $\mathbf{1 3}$ using crown ether and potassium acetate in acetonitrile [14]. Unfortunately, we found it difficult to drive the reaction to completion using the published method, obtaining only low yields of acetate $\mathbf{1 4}$ even under forcing conditions. However, performing the reaction in DMSO with potassium acetate, conditions that we have previously applied successfully [18], gave a clean reaction and high yield of acetate 14. Basic hydrolysis of crude acetate 14 produced phenol 4 of high purity and in good yield after aqueous work-up.

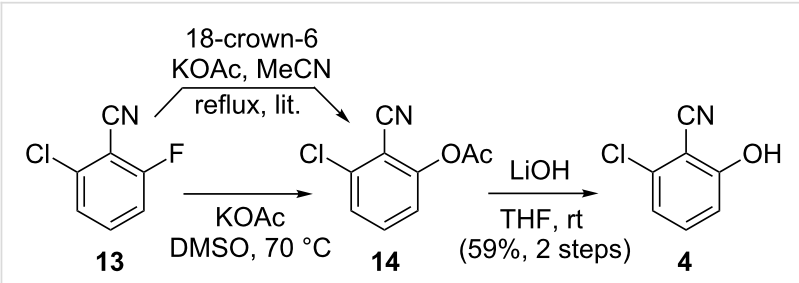

Scheme 3: Synthesis of phenol $\mathbf{4}$ from commercially available aryl fluoride 13.

With compounds $\mathbf{4}$ and $\mathbf{6}$ in hand we turned our attention to the synthesis of the remaining building block 5 (Scheme 4). In order to accurately determine the optical purity of the target molecule $(R)-3$ by chiral HPLC, we performed the synthesis of racemic rac-3 and optically pure $(R)-\mathbf{3}$ in parallel using the method by Marquis et al. [13]. Commercially available glycidol $\mathbf{1 5}$ activated as the $m$-nitrobenzene sulfonyl ( $m$-nosyl) ester $\mathbf{5}$ has previously been shown to be an ideal leaving group in reactions with aryloxy nucleophiles (e.g., 4) as it promotes direct $\mathrm{S}_{\mathrm{N}} 2$ over $\mathrm{S}_{\mathrm{N}} 2$ ' attack thereby suppressing racemisation [15]. $m$-Nosylate $\mathbf{5}$ was synthesised by using nosyl chloride at low temperature [19]. Upon cooling, the reaction mixture became a viscous slurry, and it was important to maintain vigorous stirring to ensure full conversion. In this manner, a spectroscopically pure product could be obtained in quantitative yield after simple aqueous work-up (e.g., rac-5). Alternatively, any residual alcohol 15 could be removed by chromatographic purification (e.g., $(R)-5)$. Next, the activated glycidols 5 were treated with phenol $\mathbf{4}$ in acetone under reflux and basic conditions to provide epoxides 16. Epoxides 16 were obtained in good yield after purification by column chromatography and subsequent recrystallization to remove residual starting material 5. Finally the target molecules $r a c-3$ and $(R)-\mathbf{3}$ were synthesised by ring-opening epoxides 16 with amine 6 in ethanol under reflux. ${ }^{1} \mathrm{H}$ NMR analysis of the crude product showed the presence of approximately $5-10 \%$ of a structurally similar side-product that proved extremely difficult to remove by chromatography. The side product is likely the regioisomer formed by nucleophilic attack on the more sterically hindered epoxide carbon. Fortunately, the side product could be removed by recrystallization of the hydrochloric salt of $\mathbf{3}$ to produce $3 \cdot \mathrm{HCl}$ of excellent purity and in good overall yield.

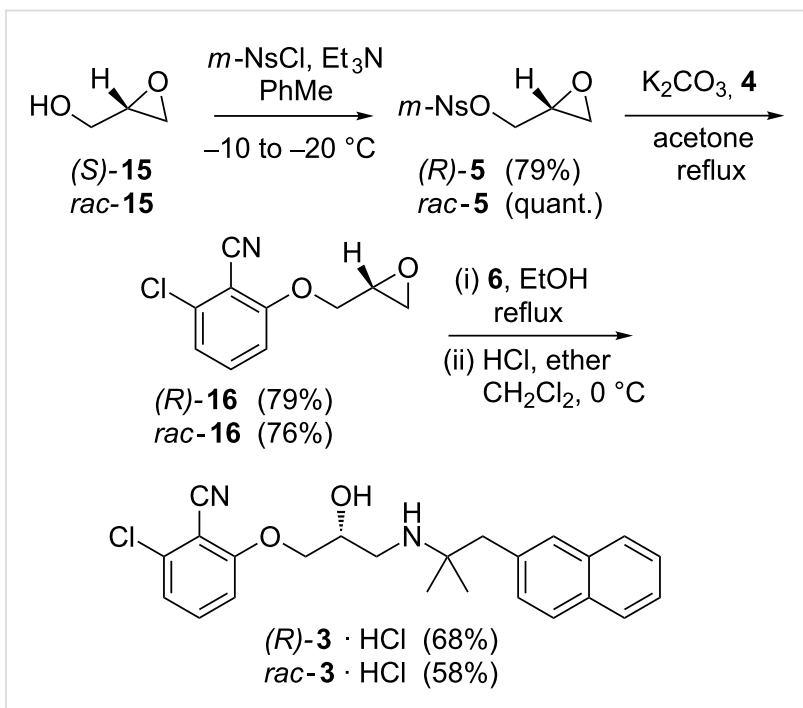

Scheme 4: Synthesis of rac-3 and $(R)-3$ from commercially available racemic- and $(S)$-glycidol 15 , respectively. Only the optically active compounds are depicted.

Analysis of optical purity by chiral HPLC showed that $(R)-\mathbf{3}$ was of excellent purity with an er $>$ 99:1 (Figure 2).

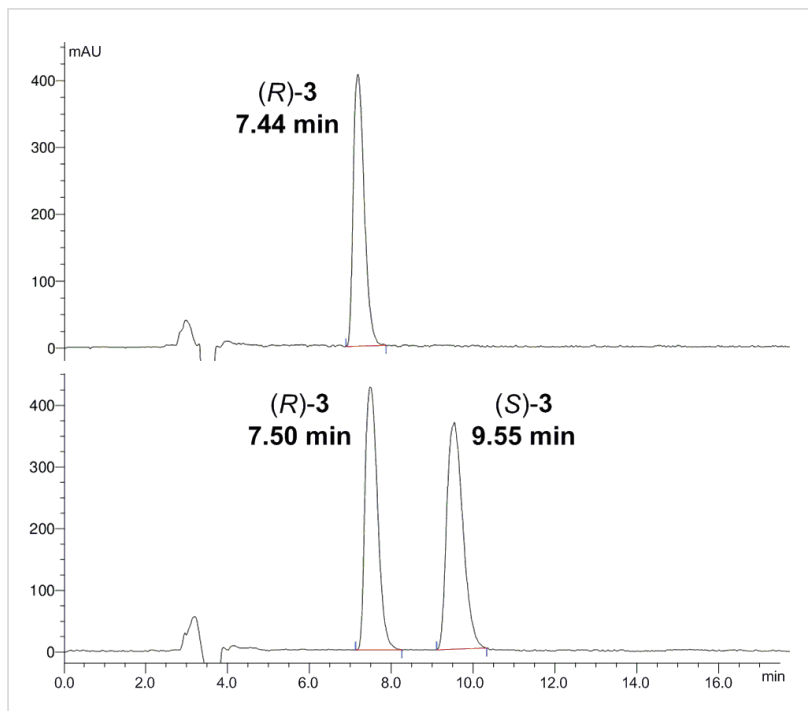

Figure 2: Determination of the optical purity for $(R)-3$ by chiral HPLC on a Daicel AD-H column. Top: Optically enriched product (er > 99:1). Bottom: Racemic sample.

Pharmacological testing of $(R)$-3 was performed as previously described [20]. (R)-3 showed inhibition of calcium-stimulated D-myo-inositol monophosphate $\left(\mathrm{IP}_{1}\right)$ accumulation in a concen- 
tration-dependent manner, with a potency consistent with that reported in the literature [21,22] $\left(\mathrm{IC}_{50}=0.64 \mu \mathrm{M}\right.$, $\mathrm{pIC}_{50}=6.3 \pm 0.2$ ), thus confirming its biological activity (Figure 3).

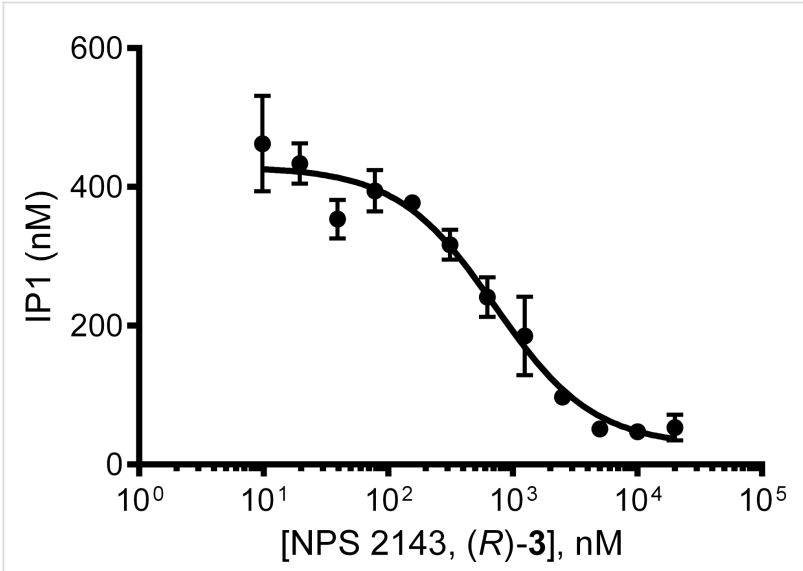

Figure 3: Characterisation of concentration-dependent $(R)-3$ inhibition of $3.5 \mathrm{mM}$ calcium-stimulated $\mathrm{IP}_{1}$ response in HEK293 cells stably transfected with rat CaSR. The graph is representative of three independent experiments.

\section{Conclusion}

Herein, for the first time, we disclose a detailed, reproducible and scalable synthetic procedure for the calcilytic ligand $(R)-\mathbf{3}$ (NPS 2143) making this important pharmacological tool compound readily available to the scientific community. All compounds have been characterised carefully and the optical purity of $(R)-3$ was deemed excellent by chiral HPLC (er $>99: 1$ ). Moreover, the pharmacological profile of $(R)-\mathbf{3}$ was consistent with that reported in the literature.

\section{Supporting Information}

${ }^{1} \mathrm{H}$ and ${ }^{13} \mathrm{C}$ NMR spectra and HPLC chromatograms for compounds $3,4,5,6,8$, and 16. Chromatograms from chiral HPLC analysis of $\mathrm{rac}-\mathbf{3}$ and $(R)-\mathbf{3}$ and experimental details for the pharmacological characterisation for $(R)-\mathbf{3}$.

\section{Supporting Information File 1}

Experimental procedures and full characterisation of the calcilytic ligand NPS 2143.

[http://www.beilstein-journals.org/bjoc/content/ supplementary/1860-5397-9-154-S1.pdf]

\section{Acknowledgements}

This work was supported by the Danish Council for Independent Research - Medical Sciences, the Lundbeck Foundation, the Carlsberg Foundation, Drug Research Academy, LEO
Pharma A/S, Aase og Ejnar Danielsens Fond, and BeckettFonden.

\section{References}

1. Lagerström, M. C.; Schiöth, H. B. Nat. Rev. Drug Discovery 2008, 7, 339-357. doi:10.1038/nrd2518

2. Overington, J. P.; Al-Lazikani, B.; Hopkins, A. L. Nat. Rev. Drug Discovery 2006, 5, 993-996. doi:10.1038/nrd2199

3. Congreve, M.; Langmead, C. J.; Mason, J. S.; Marshall, F. H. J. Med. Chem. 2011, 54, 4283-4311. doi:10.1021/jm200371q

4. Wellendorph, P.; Bräuner-Osborne, H. Br. J. Pharmacol. 2009, 156, 869-884. doi:10.1111/j.1476-5381.2008.00078.x

5. Bräuner-Osborne, H.; Wellendorph, P.; Jensen, A. A. Curr. Drug Targets 2007, 8, 169-184. doi:10.2174/138945007779315614

6. Tfelt-Hansen, J.; Brown, E. M. Crit. Rev. Clin. Lab. Sci. 2005, 42, 35-70. doi:10.1080/10408360590886606

7. Brown, E. M.; MacLeod, R. J. Physiol. Rev. 2001, 81, 239-297.

8. Feng, J.; Petersen, C. D.; Coy, D. H.; Jiang, J.-K.; Thomas, C. J.; Pollak, M. R.; Wank, S. A. Proc. Natl. Acad. Sci. U. S. A. 2010, 107, 17791-17796. doi:10.1073/pnas.1009078107

9. Chattopadhyay, N.; Brown, E. M. Mol. Genet. Metab. 2006, 89, 189-202. doi:10.1016/j.ymgme.2006.07.003

10. Kessler, A.; Faure, H.; Petrel, C.; Rognan, D.; Césario, M.; Ruat, M.; Dauban, P.; Dodd, R. H. J. Med. Chem. 2006, 49, 5119-5128. doi:10.1021/jm051233+

11. Gowen, M.; Stroup, G. B.; Dodds, R. A.; James, I. E.; Votta, B. J.; Smith, B. R.; Bhatnagar, P. K.; Lago, A. M.; Callahan, J. F.; DelMar, E. G.; Miller, M. A.; Nemeth, E. F.; Fox, J. J. Clin. Invest. 2000, 105, 1595-1604. doi:10.1172/JCI9038

12. Nemeth, E. F.; Delmar, E. G.; Heaton, W. L.; Miller, M. A.; Lambert, L. D.; Conklin, R. L.; Gowen, M.; Gleason, J. G.; Bhatnagar, P. K.; Fox, J. J. Pharmacol. Exp. Ther. 2001, 299, 323-331.

13. Marquis, R. W.; Lago, A. M.; Callahan, J. F.; Trout, R. E. L.; Gowen, M.; DelMar, E. G.; Van Wagenen, B. C.; Logan, S.; Shimizu, S.; Fox, J.; Nemeth, E. F.; Yang, Z.; Roethke, T.; Smith, B. R.; Ward, K. W.; Lee, J.; Keenan, R. M.; Bhatnagar, P. J. Med. Chem. 2009, 52, 3982-3993. doi:10.1021/jm900364m

14. Del Mar, E. G.; Barmore, R. M.; Sheehan, D.; Van Wagenen, B. C.; Callahan, J. F.; Keenan, R. M.; Kotecha, N. R.; Lago, M. A.; Southall, L. S.; Thompson, M. Method of using calcilytic compounds. U.S. Patent US6,022,894, Feb 8, 2000.

15. Klunder, J. M.; Onami, T.; Sharpless, K. B. J. Org. Chem. 1989, 54, 1295-1304. doi:10.1021/jo00267a014

16. Katritzky, A. R.; De Ville, G.; Patel, R. C. Tetrahedron 1981, 37, 25-30. doi:10.1016/0040-4020(81)85037-5

17. Kamal, A.; Chouhan, G. Tetrahedron: Asymmetry 2005, 16 , 2784-2789. doi:10.1016/j.tetasy.2005.07.022

18. Johansson, H.; Jørgensen, T. B.; Gloriam, D. E.; Bräuner-Osborne, H.; Sejer Pedersen, D. RSC Adv. 2013, 3, 945-960. doi:10.1039/c2ra21902f

19. Fagerström, A.; Nilsson, M.; Berg, U.; Isaksson, R. Org. Biomol. Chem. 2006, 4, 3067-3076. doi:10.1039/b605603b

20. Thomsen, A. R. B.; Hvidtfeldt, M.; Bräuner-Osborne, H. Cell Calcium 2012, 51, 107-116. doi:10.1016/j.ceca.2011.11.009

21. Petrel, C.; Kessler, A.; Dauban, P.; Dodd, R. H.; Rognan, D.; Ruat, M. J. Biol. Chem. 2004, 279, 18990-18997. doi:10.1074/jbc.M400724200 
22. Faure, H.; Gorojankina, T.; Rice, N.; Dauban, P.; Dodd, R. H.;

Bräuner-Osborne, H.; Rognan, D.; Ruat, M. Cell Calcium 2009, 46,

323-332. doi:10.1016/j.ceca.2009.09.004

\section{License and Terms}

This is an Open Access article under the terms of the Creative Commons Attribution License

(http://creativecommons.org/licenses/by/2.0), which permits unrestricted use, distribution, and reproduction in any medium, provided the original work is properly cited.

The license is subject to the Beilstein Journal of Organic Chemistry terms and conditions:

(http://www.beilstein-journals.org/bjoc)

The definitive version of this article is the electronic one which can be found at:

doi:10.3762/bjoc.9.154 